\title{
Exploring the Neglect of Accounting Theory in Current Academic Research in Nigeria
}

\author{
Osho, Augustine E. PhD \\ Omolola, Ramat A \\ Department of Accounting, Achievers University, Owo, Nigeria
}

Doi:10.19044/esj.2018.v14n25p156 URL:http://dx.doi.org/10.19044/esj.2018.v14n25p156

\begin{abstract}
It has become a general perception that studies in Accounting Theory, though an essential part of accounting research is gradually becoming extinct. While globally, there is a dearth of studies and researches on accounting theory, in Nigeria, such studies are literally almost nonexistent. Hence, the motivation for this study to explore the neglect of accounting theory in current academic research in Nigeria. To achieve the objectives of this study, the researchers employed case study method of research, adopting the Department of Accounting, in one of the private Universities in Nigeria as a study area. Analyzing the result of the survey, critical findings revealed among others, that factors such as Methodology, Social, Resources, Technology and Regulatory issues are the causes of neglect of accounting theory in Nigeria's Academic Area. It is recommended among others that there should be development of electronic databases of accounting researches to ease the data gathering difficulties, as well as making research and seminars in accounting theory compulsory for accounting students to stimulate interest in accounting theory in other to develop capacity and avoid extinction.
\end{abstract}

Keywords: Theory, Accounting Theory, Academic Research

\subsection{Introduction}

Hendriksen (1965), defined accounting theory as logical reasoning providing a general frame of reference by which accounting practice can be evaluated, and, the principles which guide the development of new practices and procedures. Godfrey, Hodgson, Tarca, Hamilton and Holmes, (2010) explained that, before the formalization of the double-entry system in the 1400 s, very little was written about the theory underlying accounting practices. The study further explained that, during the developmental period of the double-entry system, the main emphasis was on practice and not theory. This means that the roots of accounting theories can be traced to practice as noted 
by Hopwood (1987), who asserted that, the development of accounting emerged from practice. History of Accounting Theory can then be traced to 1494, when a Franciscan monk, Luca Pacioli, wrote the first book documenting the double-entry accounting system. Hence the theories of accounting can be said to originate from mathematics.

Over the years, the importance of Accounting Theory in academic research is being neglected globally. This assertion was empirically confirmed by Al-Adeem (2010) as shown in diagram 1 below. While the study by AlAdeem was limited to America, substantial knowledge with regards to the neglect of accounting theory in Nigeria, remains scarce. Despite numerous accounting research covering areas such as, Management Accounting, Financial Reporting, Internal Control, Corporate Governance, Financial Analysis, Forensic and Investigative Accounting, Taxation, Internal and external audit and so on, focus on accounting theory, to the best of the researcher's knowledge is limited or almost nonexistent.

Theory is defined as logical reasoning in the form of a set of broad principles that provide a general frame of reference by which accounting practice can be evaluated, and guide the development of new practices and procedures. Accounting theory is used to explain existing practices and procedures to obtain a better understanding and to provide a coherent set of logical principles that form the general frame of reference for the evaluation and development of sound accounting practices however, theory has loose and overlapping meaning with principles, concept, convention, doctrines, standards, rule, assumptions tenets postulates and procedures which are used interchangeable in this case these doctrines however gave credence to the rational judgment, universal applicability, comparability and acceptability of financial statement. Therefore, if accounting theory is agreed to be of great importance to the profession, why is there uniform perception that it is being neglected by present day accounting scholars? This is the motivation for this study. That is, to explore the neglect of accounting theory in current academic accounting research in Nigeria. In addition, the study aims to determine if current accounting researchers in Nigeria prefer studies in economics and finance over accounting topics, as well as establish the causes of neglect of accounting theory in academic research in Nigeria.

\subsection{Literature Review}

\subsection{Conceptual Framework}

\subsubsection{Concept of Theory}

Generally, theory can be described as a supposition, system of ideas and principles intended to explain something. Hendriksen (1965), defined theory as the coherent set of hypothetical, conceptual, and pragmatic principles forming the general frame of reference for a field of inquiry. Furthermore, the 
study defined accounting theory as logical reasoning in the form of a set of broad principles that provide a general frame of reference by which accounting practice can be evaluated, and in addition a guide for the development of new practices and procedures. This definition of accounting theory is widely acceptable among accounting scholars as it was widely quoted by studies such as (Gulani, 2016; Suliman, 2015; Godfrey et al, 2010; Al-Adeem, 2010) and so on.

Meanwhile, Unegbu (2014) elucidating on the history of accounting theory, explained that accounting theory is a material field that predates monetary economics. The study stated that accounting theory originated in the era of barter economy (i.e. exchange of goods for goods) when transactions were not only pre-determined by measurement but also by exchange values. The precept in which goods were exchanged at arm's length through concerted efforts of gathering, determining and measuring values are both pre and postante accounting. However, the development of accounting theory was to ameliorate the inherent problems encountered in barter economy, unlike monetary economy.

This assertion is consistent with the position of Godfrey et. al (2010), which explained that, before the formalization of the double-entry system in the 1400s, very little was written about the theory underlying accounting practices. As stated earlier, the study further explained that, during the developmental period of the double-entry system, the main emphasis, at that time was on practice and not theory. This means that the roots of accounting theories can be traced to practice as noted by Hopwood (1987) who asserted that, the development of accounting emerged from practice. History of Accounting Theory can then be traced to 1494, when a Franciscan monk, Luca Pacioli, wrote the first book documenting the double-entry accounting system, making the roots of accounting theories traceable to mathematics.

\subsubsection{Development of Accounting Theory}

According to Zalaghi (2016), the development of modern accounting theory started in America in 1936 with the establishment of the American Accounting Association (AAA). It was described as the first institutional attempt to develop a theory of accounting and the conceptual framework of accounting standards. After the establishment of AAA, Zalaghi (2016), stated that the theories of AAA were further extended by Paton and Littleton (1940), who explained in chapters of the statement on costs, income, benefit, and surplus, with most of its basic and fundamental ideas still present in the conceptual framework and standards of modern day accounting.

Jayeoba and Ajibade (2016) opined that in some countries, the professional bodies formulate the financial accounting standards, while in many others, governments and regulators establish these standards. The study 
further revealed that, historically in Nigeria, the development of accounting and accounting standards could be traced to the then Association of Accountants of Nigeria - AAN (now Institute of Chartered Accountants of Nigeria - ICAN). The AAN was formed on the 17th of November 1960 and granted official recognition on 28th September 1965, under the Federal Parliament Act number 15 of 1965, to regulate accountancy profession in the country. History suggests that ICAN was responsible for the formation of the Nigerian Accounting Standards Board (NASB) before it was taken over by government. The NASB was established in 1982, though as a private sector initiative associated with the ICAN, it first became a government parastatal in 1992 as a component of the then Federal Ministry of Trade and Tourism. The NASB issued a total of 32 Statement of Accounting Standards (SAS). The Nigerian Accounting Standards Board Act of 2003 provided the legal framework under which NASB set accounting standards. Membership includes representatives of government and other interest groups. Both ICAN and the Association of National Accountants of Nigeria (ANAN) nominate two members to the board. Later on June 3, 2011, the NASSB was replaced with the Financial Reporting Council (FRC) as the agency charged with the responsibility for, among other things, developing and publishing Accounting and Financial Reporting Standards in Nigeria.

Elucidating on the approaches to the development of accounting theory, Gulani (2016) elucidated that there are three approaches to the development of accounting theory. The approaches include; traditional, regulatory and new approaches. The study further explained that, the traditional approach include non-theoretical and theoretical approaches, with the theoretical approach categorized into deductive, inductive, ethical, sociological, economical and eclectic methods. In addition, while the regulatory approach is concerned with the adoption of either free market, private sector or public sector regulatory approach, the new approaches attempts to use both conceptual and empirical reasoning to formulate and verify an accounting framework. They include; events, behavioural, human information processing, predictive and Positive approaches. Considering all these methods and approaches towards development of accounting theories, Zalaghi (2016) while reviewing Deegan and Unerman (2006) stated that there is no universal agreement on how accounting theories should be developed. The study further stated that accounting theories were developed by applying a combination of two or more of the arguments, thereby concluding with the work of Vorster (2007) that, the development of theory is an iterative process.

\subsubsection{Role and Challenges of Academic Research in Nigeria}

Al-Adeem (2010), emphasized the importance of research and the role of the academia for the effectiveness of theory development. The study 
reinforced that accounting academicians played a critical role in advancing accounting practice by developing general accounting theory capable of guiding accounting practice. In Nigeria meanwhile, Agbi, Muhammad and Lateef (2017) explained that, the growth of accounting as a profession in Nigeria has been supported by the founding of universities, polytechnics, and colleges of technology offering accounting courses. Meanwhile, despite the critical role that research play in the development of the theory and practice of the accounting profession, the academia in Nigeria is bedeviled with deluge of myriad challenges. Some of the challenges hampering the contribution of the Nigerian accounting academia to accounting theory adapted from Agbi, Muhammad and Lateef (2017) included; insufficient research facilities in the institutions, non-availability of current accounting materials, the dearth of specialized and educational journals on accounting research, inadequate funding, and indeed, the acute shortage of accounting professors in Nigeria, which may not be unconnected to poor remuneration when compared to the private sector and other countries. Although, in contrast, Dauda, Ombugadu and $\mathrm{Aku}$ (2015) affirmed that Nigerian universities and other higher institutions of learning that run accounting programs excel in maintaining adequate standards in the teachings of accounting theory, techniques and practice. Then, why is there perceived neglect of accounting theory in academic research in Nigeria?

\subsubsection{The Structure of Accounting Theory}

According to Belkaoui (2004) as reviewed by Al-Adeem (2010), the structure of accounting theory comprises four levels:

1. A statement of the objectives of financial statements.

2. A statement of the postulates and the theoretical concepts of accounting concerned with the environmental assumptions and the nature of the accounting unit.

3. A statement of the basic accounting principles based on both the postulates and the theoretical concepts.

4. A body of accounting techniques derived from the accounting principles.

\subsubsection{Influence of Economics and Finance in Accounting Research}

Al-Adeem (2010), asserted that economics and finance are disciplines that have offered theories to accounting researchers, and that the developments in finance aimed at explaining accounting practice provided a ready basis for accounting theory. The study further articulated that the developments in the field of finance have had a radical influence on accounting research, stressing that the influence of finance and economics on accounting theories and research has been slowly and gradually increasing. In fact, the study revealed 
that, while citations from economics and finance in accounting research have increased, citations to other disciplines like law, political science, sociology, psychology, philosophy, any natural science, history, anthology, and so on disappeared in accounting research. The study also posited that finance and economics disciplines do not reciprocate such ties and reliance to accounting in their research. This means that Accounting cites finance and/or economics much more than either of them cites accounting thereby concluding that, economics and finance have been sources of most theories employed in accounting research. Meanwhile, if not reversed, this fact poses a serious threat to the continuous existence of accounting as an academic discipline.

\subsubsection{Conceptual Framework of the Neglect of Accounting Theory in Current Academic Research in Nigeria}

Bearing this in mind, and to achieve the objectives of this study, the model for this research is presented below and the determinants of the neglect of accounting theory in academic research in Nigeria is restricted to two variables viz:

a) Influence of other Discipline in Accounting Research

b) Dearth of Studies in Accounting Theory

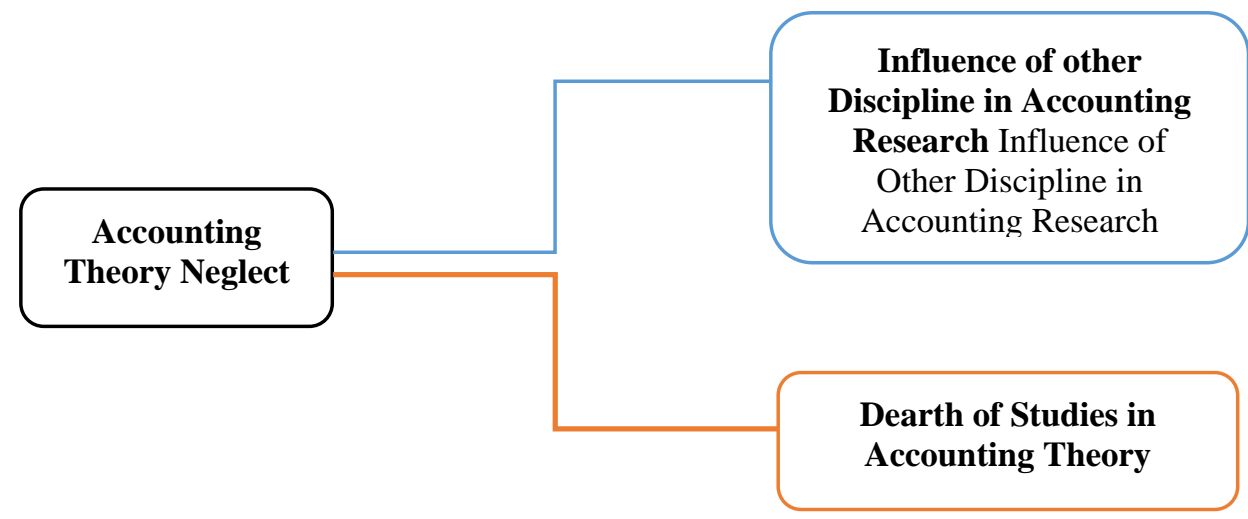

Fig. 1 - Source: Researchers' Accounting Theory in Current Academic Research in Nigeria Model

\subsection{Research Methodology}

Influenced by a subjective, constructivist paradigm, the Case Study Method of research was adopted as the design approach for this research. Qualitatively, secondary data analyzed in this study was collected by text and document review of projects submitted to the library and the Department of Accounting, of one private University's in Nigeria, for over a period of 6 (six) years from 2011 to 2016. To achieve the objectives of the study, the data 
collected were analyzed to answer the research questions and test designed hypotheses.

\subsection{Results}

\subsection{The Influence of other Disciplines in Accounting Research}

A review of all the approved final projects submitted to the library of the study area, by the Accounting Department, during the period under study was conducted to determine how many of the projects by accounting researchers conducted on fields/disciplines other than accounting during the period under review.

The researchers considered a total of 432 (four hundred and thirty-two) projects submitted to the Department of Accounting of the study area for the period under consideration. 52 per cent (226) of the projects were topics on Accounting, while 48 per cent (206) were topics from other disciplines such as Economics, Banking and Finance, Management, Human Resources and Information Technology respectively.

Table 1: Projects Submitted During the Period 2011 - 2016

\begin{tabular}{rcccccccrrr|} 
Period & $\mathbf{2 0 1 1}$ & $\mathbf{2 0 1 2}$ & $\mathbf{2 0 1 3}$ & $\mathbf{2 0 1 4}$ & $\mathbf{2 0 1 5}$ & $\mathbf{2 0 1 6}$ & Total & $\begin{array}{r}\text { percent } \\
\text { Total }\end{array}$ \\
Accounting Topics & 3 & 10 & 41 & 70 & 71 & 31 & $\mathbf{2 2 6}$ & $\mathbf{5 2}$ per cent \\
Topics from Other Discipline & 5 & 13 & 64 & 50 & 53 & 21 & $\mathbf{2 0 6}$ & $\mathbf{4 8}$ per cent \\
Total Theses & $\mathbf{8}$ & $\mathbf{2 3}$ & $\mathbf{1 0 5}$ & $\mathbf{1 2 0}$ & $\mathbf{1 2 4}$ & $\mathbf{5 2}$ & $\mathbf{4 3 2}$ & $\mathbf{1 0 0 p e r c e n t}$ \\
\hline
\end{tabular}

Source: Researchers' Field Work

Furthermore, a trend analysis of the data revealed that the first half of the period saw topics from other discipline dominating the study conducted by the researchers in the department. However, the situation improved in the second half when accounting topics became dominant, revealing improvements in motivating accounting research in the department.

This analysis has helped proffer answer in the negative to the first research question which asked "if accounting researchers prefer studies in economics and finance over accounting topics in Nigeria?" Although the margin between preference for accounting topics vis-à-vis other disciplines is very narrow, it is still established that Accounting researchers do not prefer in economics and finance and other disciplines over accounting topics in Nigeria. 


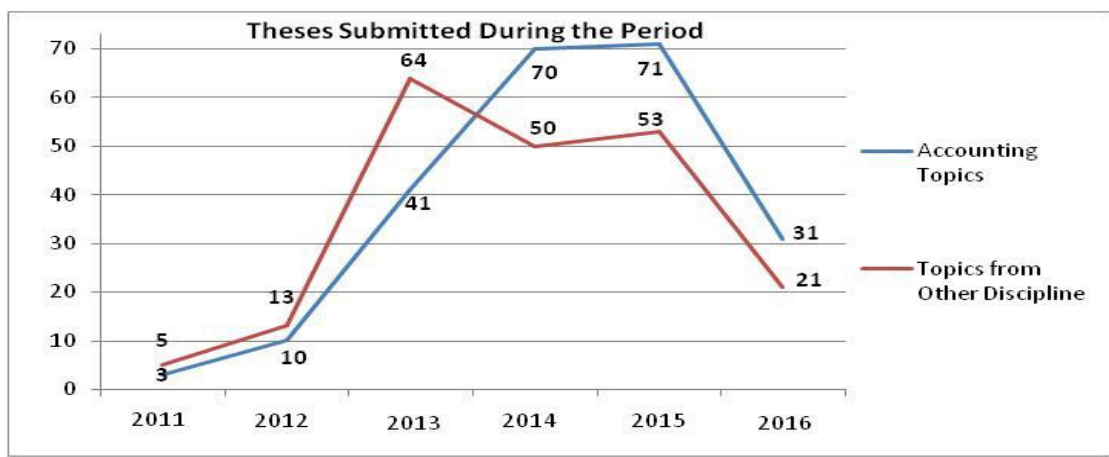

Fig. 2 - Source: Researchers' Field Work

Consequently, the first null hypothesis, $\mathrm{H}_{01}$ that:

"Accounting researchers do not prefer studies in economics and finance over accounting topics" is hereby accepted.

\subsection{Accounting Theory Topics}

In addition, this study conducted a review of all approved final projects to determine how many studies were conducted on, or related to Accounting Theory during the period under review. This revealed that, out of the 226 projects on Accounting submitted to the department, only 8 per cent (17) were topics on Accounting Theory, while a total of 92 per cent (209) were on other accounting areas such as Audit, Taxation, Public Sector Accounting, Financial Management, Internal Control, Corporate Governance, and, Financial and Management Accounting respectively.

Table 2: Topics in Accounting Theory Researched During the Period 2011 - 2016

\begin{tabular}{|rrrrrrrrrr}
$\begin{array}{r}\text { Period } \\
\text { Theory }\end{array}$ & $\mathbf{2 0 1 1}$ & $\mathbf{2 0 1 2}$ & $\mathbf{2 0 1 3}$ & $\mathbf{2 0 1 4}$ & $\mathbf{2 0 1 5}$ & $\mathbf{2 0 1 6}$ & Total & $\begin{array}{r}\text { percent } \\
\text { Total }\end{array}$ \\
Topics & 1 & 0 & 4 & 6 & 6 & 0 & $\mathbf{1 7}$ & $\mathbf{8}$ per cent \\
Other Accounting Topics & 2 & 10 & 37 & 64 & 65 & 31 & $\mathbf{2 0 9}$ & $\mathbf{9 2}$ per cent \\
Total Theses & $\mathbf{3}$ & $\mathbf{1 0}$ & $\mathbf{4 1}$ & $\mathbf{7 0}$ & $\mathbf{7 1}$ & $\mathbf{3 1}$ & $\mathbf{2 2 6}$ & $\mathbf{1 0 0 \text { percent }}$ \\
\hline
\end{tabular}

Source: Researchers' Field Work

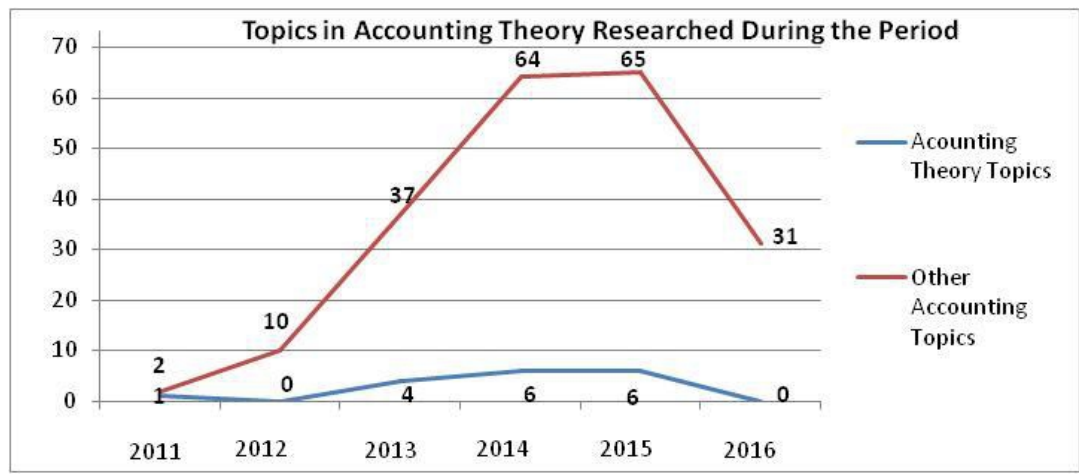

Fig. 3- Source: Researchers' Field Work 
This analysis has helped answer in the affirmative the second research question which asked "if accounting theory is being neglected by accounting researchers in Nigeria?" The margin between preference for studies in accounting theory, vis-à-vis other areas of accounting is very wide. This has established that Accounting researchers avoid conducting studies on Accounting Theory.

Consequently, the second null hypothesis $\mathrm{H}_{0} 2$ that:

"There is no neglect of accounting theory by accounting researchers in Nigeria" is hereby rejected.

Table 3: Test of Hypotheses Result Summary

\begin{tabular}{|c|c|c|}
\hline $\mathbf{H}_{01}$ & $\begin{array}{c}\text { Accounting researchers do not prefer studies in economics and finance } \\
\text { over accounting topics. }\end{array}$ & Accept \\
\hline $\mathbf{H}_{\mathbf{0 2}}$ & There is no neglect of accounting theory by accounting researchers in & Reject \\
& Nigeria. & \\
\hline
\end{tabular}

Source: Researchers' Field Work

\subsection{Causes of Neglect of Accounting Theory in Academic Research in Nigeria}

Since the second hypothesis has been rejected, the third research question of this study is apt in determining the causes of the neglect of accounting theory in academic research, as perceived by accounting researchers in Nigeria. The researchers adopted unstructured interview methods of data gathering to find out the perception of accounting scholars and researchers on why they would rather research on other area of accounting or even other disciplines entirely other than Accounting Theory. The researchers sampled the opinions of a total of twenty (20) respondents, eight (8) accounting scholars and twelve (12) postgraduate accounting students respectively.

Although Latham (2013) recommended the "sweet spot" sample size for qualitative studies as between fifteen (15) to twenty (20) for homogeneous groups, and a saturation point of twelve (12) for most studies; after nine (9) participants, this study got to saturation with no additional insight from interviewees.

The causes of neglect as compiled from interview data can be summarized into 5 major factors namely; Methodology, Social, Resources, Technology and Regulatory in descending order.

1) Methodology: Methodology ranked highest as ten (10) interviewees believed it is the major factor in the neglect of Accounting Theory in Accounting Research. It consists of difficulties in gathering data for research in accounting theory and the scarcity of Accounting Theory research materials.

2) Social issues: Social issues ranked second highest as nine (9) interviewees believed it is another major factor in the neglect of Accounting Theory in 
Accounting Research. It consists of difficulties in gathering data for research in accounting theory and the scarcity of Accounting Theory research materials. The social issues raised by interviewees include continuous acrimony between scholars and professionals/practitioners, and indeed among professionals. Some also expressed that accounting theory is dull, boring and very difficult to understand for average students.

3) Resources: Next on the challenges causing the neglect of accounting theory was non availability and inadequate research resources for optimal studies in accounting theory. These issues as summarized by seven (7) interviewees include poor funding of accounting research as a contributing factor to the neglect of accounting theory, overdependence and reliance on theories from other disciplines especially economics and finance by accounting researchers due to inadequacy of modern day accounting theory and theorists. Another issue raised by an interviewee is the inadequacy of seasoned academics and scholars who can mentor upcoming academics on accounting theory, as well as the lack of easy accessibility and availability of accounting journals in Nigeria for review and publication of accounting studies in Nigeria.

4) Technology: Another critical point raised by respondents (majorly postgraduate students) as influencing the neglect of Accounting Theory in Nigeria is the advent and proliferation of technology in accountancy. The introduction of Accounting Software's and Packages and wide acceptance and adoption in the practice of accounting has helped relegated the importance of research into the theories, principles and concepts of accounting. This is so as accounting theories and principles mostly has been built into the systems as business rules, thereby making further studies and researches look unnecessary.

5) Regulatory Framework: Finally, respondents opined that the regulatory framework of accounting in Nigeria has also not helped in encouraging studies in accounting theory. This assertion was reinforced by 3 scholars, and the main reason given was the exclusion of academics on the board of the Financial Reporting Council (FRC). They suggested that the influence of the academia on the 19 member board of the Council will go a long way to stimulate researches in accounting theory. 


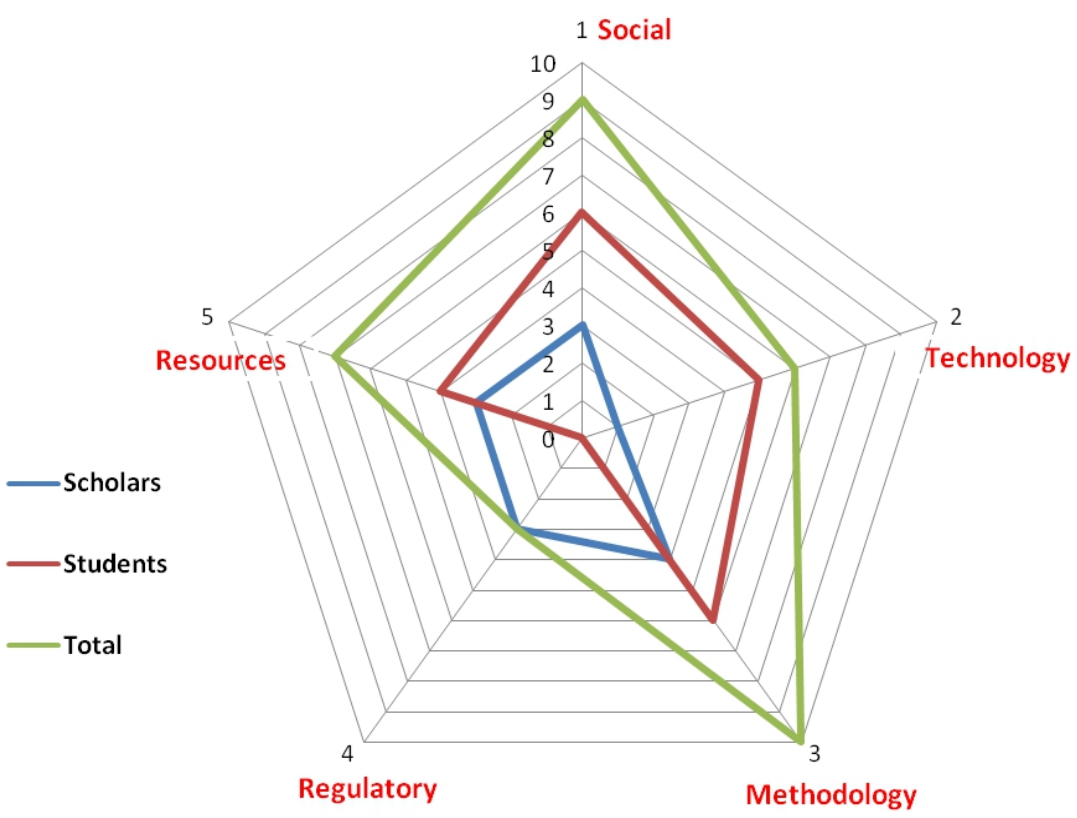

Causes of Neglect of Accounting Theory in Accounting Research

Fig. 4 - Source: Researchers' Causes of Neglect of Accounting Theory in Accounting Research Model

\subsection{Summary and Conclusion}

This study has succeeded in confirming two things. First is the fact that researchers do not prefer studies in economics and finance over accounting topics in their studies. The second is the confirmation that indeed, accounting theory is becoming neglected in academic research in Nigeria. The perceived reasons and causes of this neglect are discussed above.

Based on the above findings, these problems threaten the very existence of accounting as an academic discipline. As a result, this study proffers the following as solutions to the problem, if implemented:

a) The development of automated accounting research databases to ease the difficulties in gathering data for research with special focus on accounting theory. This idea can be implemented by the libraries of academic institutions, professional bodies and even a private repository. Access to this database should be affordable.

b) Academic institution should make research or seminars in accounting theory compulsory to stimulate interest in the area to avoid extinction and also develop capacity.

c) Scholars, professional bodies and accounting practitioners should form a formidable coalition with the aim of bridging the gaps in accounting research. 
d) Scholars should make the delivery of accounting theory lectures interesting and encouraging for students to understand and also stimulate their research interests.

e) The government and other research institutions support accounting research with the provision of adequate funding for accounting research.

f) Accounting scholars supervising thesis and reviewing seminars in accounting topics should encourage theoretical framework based on the use accounting theories to reduce or even eliminate the overdependence and reliance on theories from other disciplines especially economics and finance.

g) Conclusively, a union of accounting scholars with keen interest on the development of accounting theory should be formed. This body should have representation on the board of the Financial Reporting Council (FRC).

Finally, based on the above findings, it is recommended that the following researcher(s) who may wish to further this study should focus on other disciplines of study.

\section{References}

1. Agbi, E. S., Muhammad, B. M. \& Lateef, O. M. (2017). Historical Development Of Accounting Profession In Nigeria: Threats And Issues, International Journal of Business and Management Review Vol.5, No.10, pp.89-100, December 2017

2. Al-Adeem, K. R. (2010). Accounting Theory: A Neglected Topic in Academic Accounting Research, Unpublished PhD disertation, Case Western Reserve University

3. Cochran, W. G. (1977). Sampling Techniques, New York, John Wiley \& Sons.

4. Creswell, J. W. (2014). Research design: Qualitative, quantitative, and mixed method approaches, 2nd ed., Sage Publications

5. Dauda, I. A., Ombugadu, B. A. \& Aku, S. U. (2015). Threats and Challenges to Accounting Profession: A Draw Back to the Development of Accounting Practices in Nigeria, International Journal of Academic Research in Accounting, Finance and Management Sciences Vol. 5, No.4, October 2015, pp. 96-104 E-ISSN: 2225-8329, P-ISSN: 2308-0337, www.hrmars.com

6. Gaffikin, G. (2005). The demand and supply of accounting theories: the market for excuses. The Accounting Review, (54), 273-395

7. Gheondea-Eladi, A. (2014). Is Qualitative Research Generalizable? Journal of Community Positive Practices, XIV (3) 2014, 114-124 ISSN Print: 1582-8344; Electronic: 2247-6571 
8. Godfrey, J., Hodgson, A., Tarca, A., Hamilton, J., \& Holmes, S. (2010). Accounting Theory 7th ed., John Wiley \& Sons, Australia

9. Gulani, M. G. (2016). Accounting Theory, University of Maiduguri, Nigeria

10. Hendriksen, E. S. (1965). Accounting Theory (1st ed.). New York, NY: McGraw-Hill

11. Hopwood, A. G. (1987). "The archeology of accounting systems." Accounting, Organizations and Society. 12 (3): 207-234

12. Jayeoba, O. O. \& Ajibade, A. T. (2016). Evolution Of Accounting Standards In Nigeria: A Historical PerspectiveInternational Journal of Advanced Academic Research | Social \& Management Sciences | ISSN: 2488-9849 Vol. 2, Issue 8

13. Latham, J. (2013). Qualitative Sample Size - How Many Participants is Enough? Retrieved from Https://www.grjohnlatham.com/manyparticipant-enough/ on July 27, $20183.34 \mathrm{pm}$

14. Paton, W. A. and Littleton, A. C. (1940). An Introduction to Corporate Accounting Standards

15. Saunders, N, Lewis, P. \& Thornhill, A. (2012). Research Methods for Business Students, United Kingdom, Pearson Education

16. Suliman, C. (2015). Theory and Accounting Theory The British Institute, Kolkata

17. Unegbu, A. O. (2014). Theories of Accounting: Evolution \& Developments, Income Determination and Diversities in Use. Research Journal of Finance and Accounting ISSN 2222-1697 (Paper) ISSN 2222-2847 (Online) Vol.5, No.19, 2014

18. Vorster, Q. (2007). The Conceptual Framework, Accounting Principles and what we believe is true. Accountancy S; Accounting \& Tax periodicals, pp. 30-33

19. Zalaghi, H. (2016). The Role of Deductive and Inductive Reasoning in Accounting Research and Standard Setting, Asian Journal of Finance \& Accounting ISSN 1946-052X 2016, Vol. 8, No. 1 www.financilareportingcouncil.gov.ng/about-us/governing-bodies/ 